\title{
Phylogenetic position of Ecballocystis and Ecballocystopsis (Chlorophyta)
}

\author{
Shuang XIA ${ }^{1,2}$, Huan ZHU ${ }^{1,2}$ Ying-Yin Cheng ${ }^{1}$, Guo-Xiang LiU ${ }^{1 *}$ \& Zheng-Yu \\ $\mathrm{Hu}^{1}$
}

${ }^{1}$ Key Laboratory of Algal Biology, Institute of Hydrobiology, Chinese Academy of Sciences, Wuhan 430072, P. R. China; *Corresponding author e-mail: liugx@ihb.ac.cn

${ }^{2}$ University of Chinese Academy of Sciences, Beijing 100039, P. R. China

\begin{abstract}
Ecballocystis and Ecballocystopsis are two rare, green algal genera. Both have thalli that grow on rock surfaces in flowing water and attach to rocks by a thick mucilaginous pad. The algae have similar thalli structure, consisting of autospores in mother cell wall remnants. Ecballocystopsis differs from Ecballocystis in being filamentous instead of dendroid. In this study, new strains of Ecballocystis hubeiensis and Ecballocystopsis dichotomus were collected from China and cultured. Morphology was observed by light and electron microscopy. $18 \mathrm{~S}$ rDNA and $r b c \mathrm{~L}$ sequences were determined and subjected to phylogenetic analysis. Both morphological and phylogenetic analysis indicated that Ecballocystis and Ecballocystopsis should be placed in the family of Oocystaceae. Ecballocystis was closely related to Elongatocystis in 18S rDNA phylogeny. The results of present study emphasize the high level of phenotypic plasticity of Oocystaceae. Within the family, cell arrangement can be solitary, colonial, dendroid, or filamentous.
\end{abstract}

Key words: Ecballocystis, Ecballocystopsis, phylogeny, 18S rDNA, rbcL, Oocystaceae

\section{Introduction}

Ecballocystis BoHLIN and Ecballocystopsis IYENGAR are two rare green algal genera. Both algae grow on the wet surfaces of substrata. The genus Ecballocystis was established by BoHLIN in 1897 with the type species Ecballocystis pulvinata BoHLin. Until now, six species, five varieties and two forms have been recorded from India, South Africa, Réunion Island, and China (FrITSCH 1918; Iyengar 1932; Bourrelly \& Couté 1986; Liu \& Hu 2005). The taxonomic position of the genus Ecballocystis has been debated. It was originally ascribed to Chlorodendraceae, Tetrasporales, but the author pointed out its similarities with Oocystis (Iyengar 1932). Philipose (1967) thought it to be a member of Chlorococcales. BourRelly (1966, 1972, 1988) included it in Hormotilaceae or Palmellaceae, Chlorococcales. KomÁreK and FotT (1983) ascribed it to Botryococcaceae of the order Chlorococcales. The species of Ecballocystis hubeiensis Liu et Hu was described first from China with one obvious character, macroscopic colonies as large as $300 \sim 650 \mu \mathrm{m}$, distinguishing the species from other members of Ecballocystis (LiU \& Hu 2005).

The genus Ecballocystopsis was established by IYENGAR (1933) with the type species Ecballocystopsis indica Iyengar. Three species have been reported from India and China up to now (Iyengar 1933; Prasad 1985; Hu \& BI 1998). The genus Ecballocystopsis was originally ascribed to Chlorodendrales, while Fritsch (1956) placed it in the Chlorodendraceae, Volvocales. Ecballocystopsis dichotomus $\mathrm{Hu}$ et $\mathrm{BI}$ was described first from China with two morphological features-dichotomously branched colonies and loops in the branches - distinguishing it from the two previously reported members of Ecballocystopsis (Hu \& BI 1998).

However, it became evident that the initial and provisional assignment of the two algae was incorrect. Both algae exhibit cell structures and multilayered cell walls similar to those of Oocystaceae, but they form large thalli that can be seen with the naked eye in contrast to most members of the Oocystaceae.

In this study, we investigated the 
taxonomic placement of Ecballocystis hubeiensis and Ecballocystopsis dichotomus by collecting and characterizing new strains from natural habitats. The strains were cultivated in the lab, cell morphology was observed by light and transmission electron microscopy (TEM), and phylogenetic analysis of $18 \mathrm{~S}$ rDNA and $r b c \mathrm{~L}$ sequences was performed.

\section{Materials and Methods}

Sampling and cultivation. Samples of Ecballocystis hubeiensis were collected from Jiugongshan Mountain Nature Conservation area $\left(29^{\circ} 25^{\prime} \mathrm{N}, 114^{\circ} 32^{\prime} \mathrm{E}\right)$, Tongshan County, Hubei Province, on rocks kept moist by small waterfalls in August 1999 and June 2010. Samples of Ecballocystopsis dichotomus were collected from a village in Zhuxi county $\left(32^{\circ} 20^{\prime} \mathrm{N}\right.$, $114^{\circ} 10^{\prime} \mathrm{E}$ ), Hubei Province, from irrigation ditches in August 1999 and June 2010.

Environmental samples were rinsed in BBM (BISChoff \& Bold 1963) medium, and then the algae were grown as uni-algal cultures in culture dishes on sterilized BBM medium solidified with $1 \%$ agar under a constant light source of $30 \sim 50 \mu \mathrm{mol} . \mathrm{m}^{-2} \cdot \mathrm{s}^{-1}$ and a temperature of $25{ }^{\circ} \mathrm{C}$. The medium was renewed every 2 to 3 weeks until sufficient biomass $(>0.5$ $\mathrm{g}$ fresh mass) was obtained for DNA extraction. Cultures can be obtained from the Freshwater Algae Culture Collection, Institute of Hydrobiology, Chinese Academy of Science (FACHB) under the accession Nos. FACHB-1229 and FACHB-1230 upon request.

Morphological observations. For light microscopy, living cells and fixed cells were observed by differential interference contrast (DIC) and epifluorescence microscopy (EFM) using a Leica DM5000B microscope. Micrographs were taken with a Leica DFC320 digital camera. For TEM, cells were fixed in $3 \%$ glutaraldehyde in $0.1 \mathrm{M}$ cacodylate buffer and then fixed in $1 \%$ aqueous $\mathrm{OsO}_{4}$ in $0.1 \mathrm{M}$ cacodylate buffer, dehydrated in acetone, embedded in Spurr's resin, and ultrathin sections were stained with uranyl acetate and lead citrate (ReYNOLDS 1963). Electron micrographs were taken with a Tecnai 12 (FEI) microscope equipped with a Gatan CCD camera.

DNA isolation, PCR amplification and sequencing. Algal cultures were rinsed in $\mathrm{ddH}_{2} \mathrm{O}$ three times and then harvested by centrifugation. The algal cells were broken with mini beads in a beadbeater (3110BX, Biospec Products, Bartlesville, USA). Total DNA was extracted using a CTAB method (Doyle \& Dickson 1987).

To obtain the $r b c \mathrm{~L}$ genes, common primers were used as described by Zechman (2003). The $18 \mathrm{~S}$
rDNA sequence of Ecballocystopsis dichotomus was amplified from total genomic DNA with eukaryotespecific primers as described by MeduIN et al. (1988). Universal primers were unsuccessful with Ecballocystis hubeiensis, so specific primers were designed targeting conserved areas of the 18S rDNA sequences of Oocystaceae. The sequences of the specific primers were as follows: Ec18SF, 5'-GGTTG ATCCT GCCAG TAG-3'; Ec18SR, 5'-TACGA CTTCT CCTTC CTCTA-3'. The polymerase chain reaction (PCR) was carried out with Blend Taq Polymerase (Toyobo, Tokyo, Japan). The PCR cycling conditions were as follows: 4 min initial denaturation at $95^{\circ} \mathrm{C} ; 35$ cycles of denaturation at $95^{\circ} \mathrm{C}$ for $1 \mathrm{~min}$, primer annealing at $55^{\circ} \mathrm{C}(18 \mathrm{~S} \mathrm{rDNA})$ or $50^{\circ} \mathrm{C}(r b c \mathrm{~L})$ for $1 \mathrm{~min}$, and extension at $72^{\circ} \mathrm{C}$ for $2 \mathrm{~min}$; and a final extension of 10 min at $72{ }^{\circ} \mathrm{C}$.

The PCR products were visualized by staining with ethidium bromide following electrophoresis in $1 \%$ agarose. The products were purified with the E.Z.N.A. Gel Extraction Kit (OMEGA) and sent to Sangon Biotech Inc., China, for sequencing. The sequences were assembled with Seqman (Swindell \& Plasteer 1997) and were deposited in Genbank under the Accession Nos. JX018184 JX018187.

Sequence alignment and phylogenetic reconstruction. Sequences of putative relatives were downloaded from Genbank. The sequences were initially aligned with ClustalX 1.83 (THompson et al. 1997), and refined manually in SEAVIEW (Gouy et al. 2010). Homology of sites and accuracy of the alignments were determined by examining secondary structure calculated in RNAstructure 4.11 (MATHEws et al. 1999) based on a predicted secondary structure model (Luo et al. 2006). The final alignment of $18 \mathrm{~S}$ rDNA sequences comprised a matrix of 34 sequences including Prasiola mexicana (Prasiolaceae) as an outgroup taxon, while the alignment of $r b c \mathrm{~L}$ sequences included 25 taxa with Chara connivens (Characeae) as outgroup. The alignments are available from the authors upon request.

Mutational saturation was evaluated in the variable positions of the alignments by plotting pairwise distances against model-corrected distances for Tamura and Nei (1993) and Kimura (1980) models and estimated in MEGA (v.4.0) (TAMURA et al. 2007).

Phylogenies were estimated using maximum likelihood (ML) in PAUP 4.0*(v. 4.0 beta) (SwOFFord 1998) and Bayesian inference (BI) in MrBayes (v. 3.1.2) (HuelsenBeCK et al. 2001). For ML analysis, ModelTest 3.06 (Posada \& Crandall 1998) was executed to select the evolutionary best-fit model under the Hierarchical Likelihood Ratio Tests (hLRTs) and Akaike Information Criterion (AIC). The best-fit models of $18 \mathrm{~S}$ rDNA and $r b c \mathrm{~L}$ datasets were TIM $+\mathrm{G}$ and $\mathrm{GTR}+\mathrm{G}$ separately. In ML analysis, a heuristic search option with random addition of sequences (100 replicates) and the tree bisection and reconnection 
branch-swapping algorithm were used for tree searching. Bootstrap analysis with 1000 replicates of the dataset for ML was performed to estimate statistical reliability. A Bayesian Markov Chain Monte Carlo analysis was run with seven Markov chains (six heated chains, one cold) for 5000000 generations with trees sampled every 1000 generations. The first 1250 trees (burn-in samples) were discarded, and the remaining samples were used to construct a Bayesian consensus tree and to infer posterior probability.

\section{Results}

\section{Morphology}

Light microscopy. Ecballocystis hubeiensis formed macroscopic dendroid colonies with numerous irregular branches (Figs 1, 2). Cells produced 2 8 autospores/daughter cell. Daughter cells were situated nearly parallel in a common mucilaginous sheath. Common sheaths were connected to one another loosely, more or less end to end, to form the irregular branches (Fig. 3 ). Adjacent cells contacted each other at points below the cell apex (Fig. 4). Cells were oval, rarely round, 12-35 $\mathrm{m}$ long, and 6-15 $\mu \mathrm{m}$ wide (Fig. $5)$. Each cell had 2 6 parietal discoid chloroplasts (Fig. 6).

When maintained in culture dishes, no macroscopic branched colony could be observed. Most cells were arranged in small colonies consisting of 4, 8, or 16 daughter cells, and their mother cell walls were easy to rupture (Figs 7, $8)$.

Ecballocystopsis dichotomus formed dichotomously branched colonies, attached to substrata by mucilaginous pads at the base (Figs 10,11). Filaments had primary and frequent secondary branches. Loops were observed in the middle of filaments. Branching or loops originated from several transverse divisions following longitudinal division of a cell in the end or in the middle (Figs 12, 13, 14). The connection between branches was very loose. Cells were cylindrical, $20-45 \mu \mathrm{m}$ long, and 7-14 $\mu \mathrm{m}$ wide (Fig. 15). Each cell had 16-24 parietal discoid chloroplasts (Fig. 16), each with one ellipsoidal pyrenoid. Cells of successive generations were arranged in a row.

Under favorable conditions, the cells of Ecballocystopsis dichotomus divided quickly on agar medium. Because the thalli did not experience the force of external water flow, which can push new cells forward, continued cell division resulted in the thallus becoming a solid cylinder-like filament composed of several rows of cells. The thick cylinders were composed of small colonies, in which 2 or 4 autospores were contained within a common cell wall (Figs 17, 18).

Scanning electron microscopy. In each chloroplast of Ecballocystis hubeiensis, one global pyrenoid with a homogenous matrix was situated and surrounded by a thick starch sheath. The diameter of the pyrenoid body was between 1 and $1.5 \mu \mathrm{m}$; the thickness of the starch sheath was about $0.3 \mu \mathrm{m}$. Thylakoids extended the length of the chloroplast and occurred in stacks of three to five, but never traversed the pyrenoid matrix. The starch sheath around the pyrenoid appeared like a closed ring (Figs 20, 21).

The pyrenoid of Ecballocystopsis dichotomus was surrounded by a starch sheath. No thylakoids contacted the surface of the pyrenoid or penetrated the pyrenoid matrix. The diameter of the pyrenoid body was between 1 and $2 \mu \mathrm{m}$; the thickness of the starch sheath was about 0.3 $\mu \mathrm{m}$. Thylakoids did not traverse the pyrenoid matrix. Starch grains were observed in the matrix of chloroplasts (Figs 22, 23). Daughter cells were situated in the mother cell wall (Fig. 24). Walls of adjacent cells gradually gelatinized except at the two ends.

\section{Ecology}

Ecballocystis hubeiensis grew on rock surfaces and kept moist by waterfalls or water drops (Fig. 9). It grew profusely in summer. When the velocity of water flow was high, the branches of E. hubeiensis were long and thin (Fig. 2), composed of cells with a length-width ratio about 3-4; when a long drought dried up the water source, the mucilage became concentrated and the branches of E. hubeiensis were short and thick (Fig. 1), composed of cells with a length-width ratio about 2 .

Ecballocystopsis dichotomus grew epiphytically on rocks and other substrata under or near flowing water (Fig. 19). It grew well in summer and dried in autumn.

\section{Phylogeny}

The PCR amplicons of the 18S rDNA of Ecballocystis hubeiensis and Ecballocystopsis dichotomus was about 2500bp and 1700bp long, respectively. Excluding introns, the $18 \mathrm{~S}$ rDNA sequences of the isolates and their putative relatives analyzed in this study were 1562 nucleotides long. Among these nucleotides, 


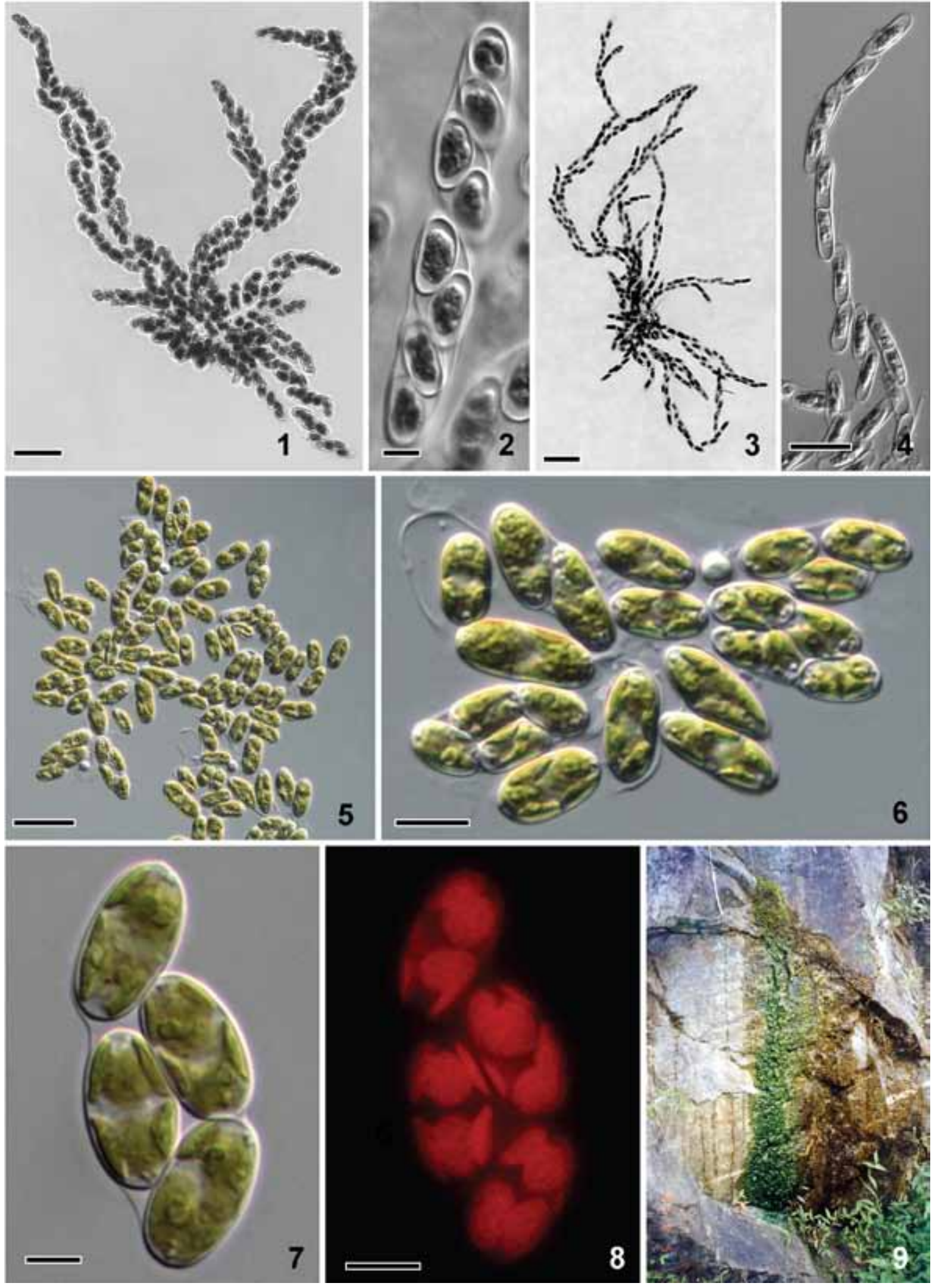

Figs 1-9. Ecballocystis hubeiensis in the field $(1-4,9)$ and in culture (5-8): (1) colony with short and thick branches, grown in low water flow; (2) colony with long and thin branches, grown in high water flow; (3) daughter cells situated in a common mucilaginous sheath forming a branch; (4) adjacent cells contacting each other at points below the cell apex; (5) detail of the cells and the common mucilaginous sheath; (6) same cells as in Fig. 5, autofluorescence showing the shape and number of chloroplasts; $(7,8)$ cells in culture arranged in small colonies; (9) natural habitat with the thalli attached on the surface of a rock under a waterfall. Scale bar $50 \mu \mathrm{m}(1,2,7), 10 \mu \mathrm{m}(3-6,8)$. 

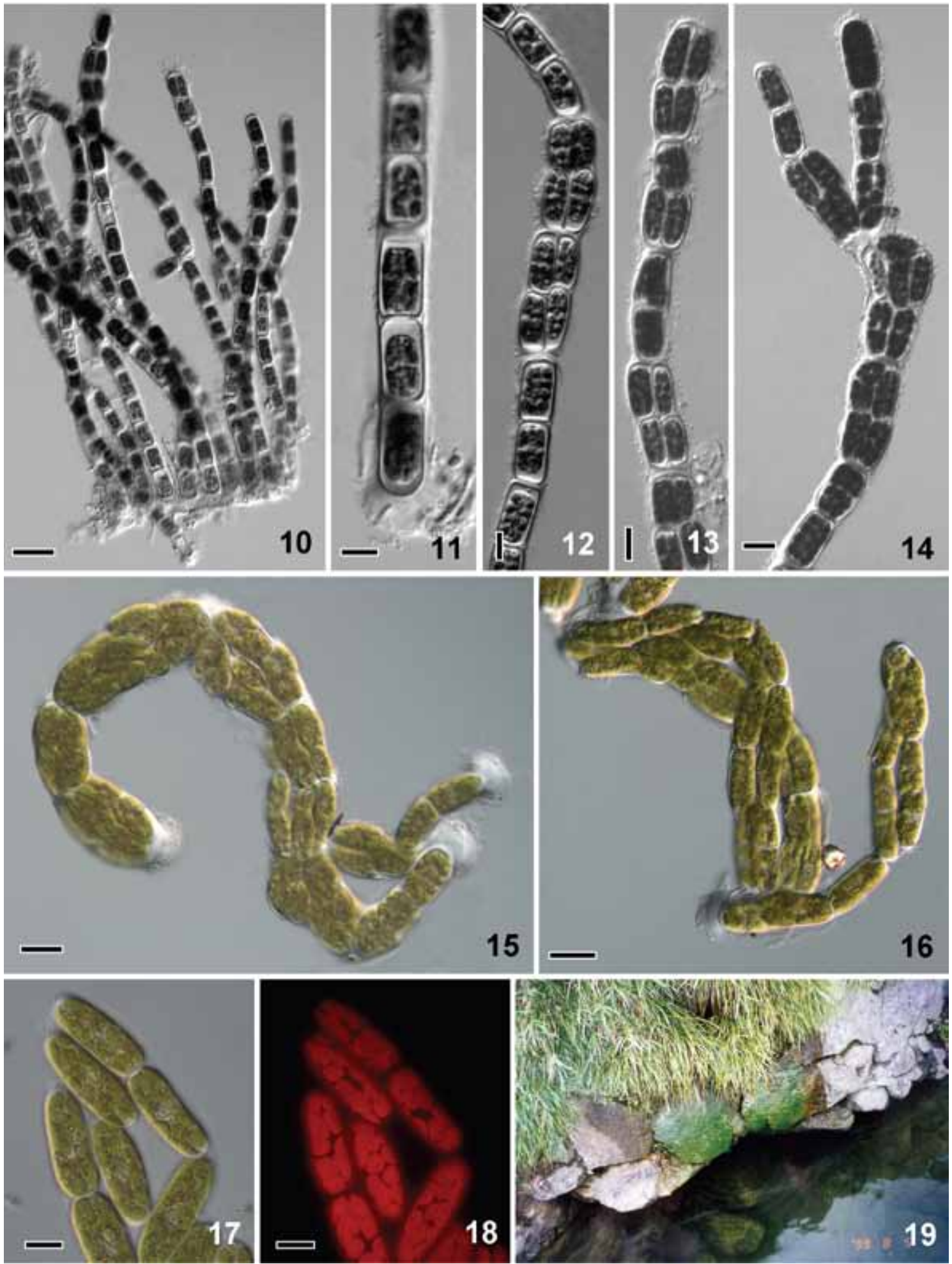

Figs 10-19. Ecballocystopsis dichotomus in the field $(10-14,19)$ and in culture $(15-18)$ : $(10,11)$ filamentous thallus with a mucilaginous pad at the base; (12) cell division forming a loop in the middle of a filament; $(13,14)$ cell division forming a dichotomous branch at the end of a filament; (15) autospores in mother cell walls; (16) same cells as in Fig. 17 with autofluorescence showing the shape and number of chloroplasts; $(17,18)$ thalli on agar medium forming thick cylinders composed of several rows of cells; (19) natural habitat with the thalli growing on the surface of a rock with seeping water. Scale bar $50 \mu \mathrm{m}(10), 20 \mu \mathrm{m}(17,18), 10 \mu \mathrm{m}(11-14,15,16)$. 

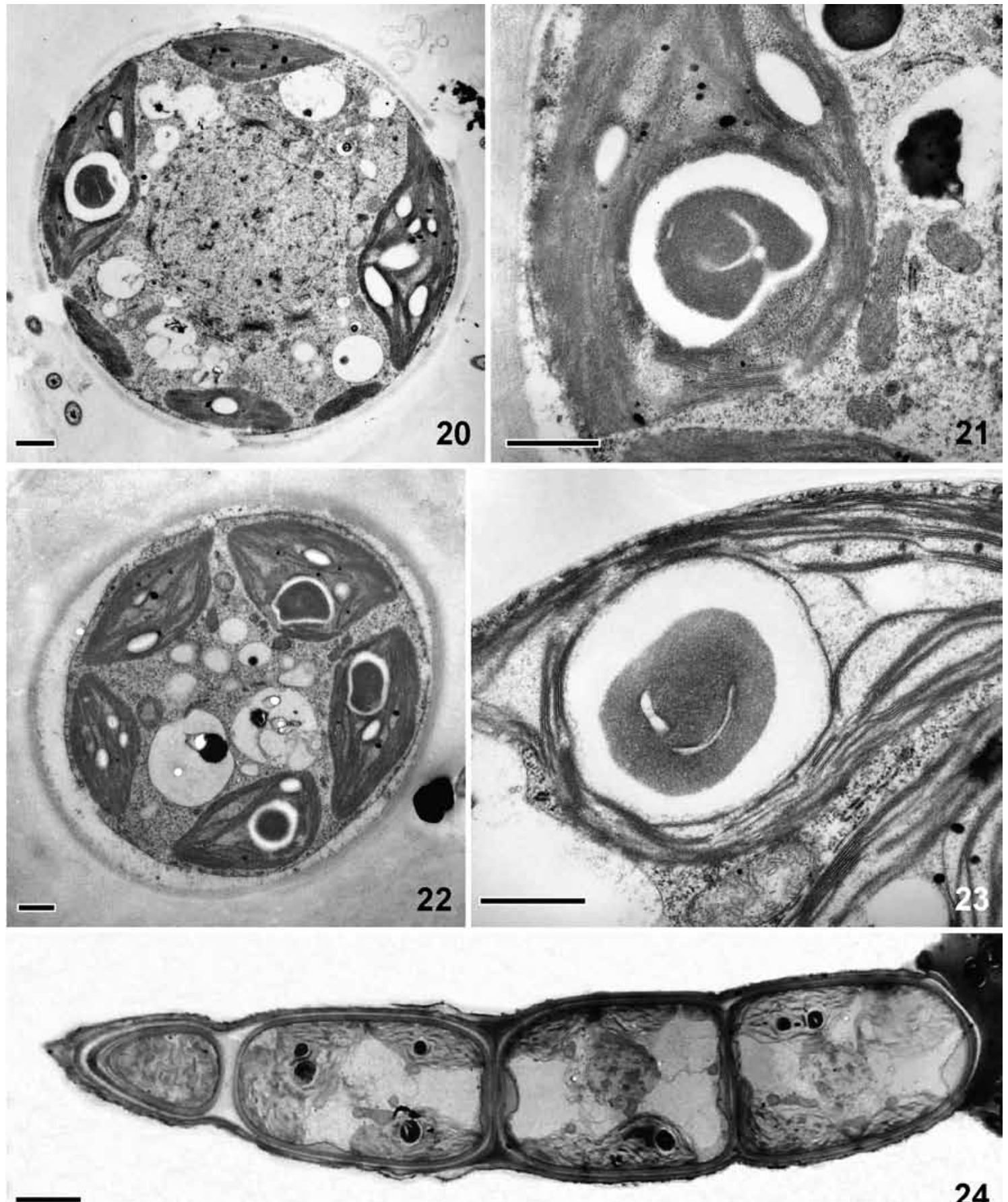

Figs 20-24. Electron microscopy of Ecballocystis hubeiensis (20, 21) and Ecballocystopsis dichotomus (22-24): (20, 22) transverse section of a cell, showing several chloloplasts; $(21,23)$ detail of the pyrenoid surrounded by a starch sheath and the thylakoids; (24) cells within a common cell wall. Scale bar $1 \mu \mathrm{m}(20-23), 5 \mu \mathrm{m}(24)$.

1139 sites $(72.9 \%)$ were variable and 713 sites $(45.6 \%)$ were parsimoniously informative. Base frequencies across the 34 taxa were found to be homogeneous. The overall average pairwise distance was 0.184 .

The PCR amplicons of the $r b c \mathrm{~L}$ sequences of Ecballocystis hubeiensis and Ecballocystopsis dichotomus was about $1300 \mathrm{bp}$ long. The alignment of the isolates and their putative relatives analyzed in this study were 1043 nucleotides long. Among these nucleotides, 425 sites $(40.7 \%)$ were variable and 342 sites (32.8\%) were parsimoniously informative. Base frequencies across the 25 taxa were found to be homogeneous. The overall average pairwise distance was 0.157 .

The phylogenetic trees constructed by 


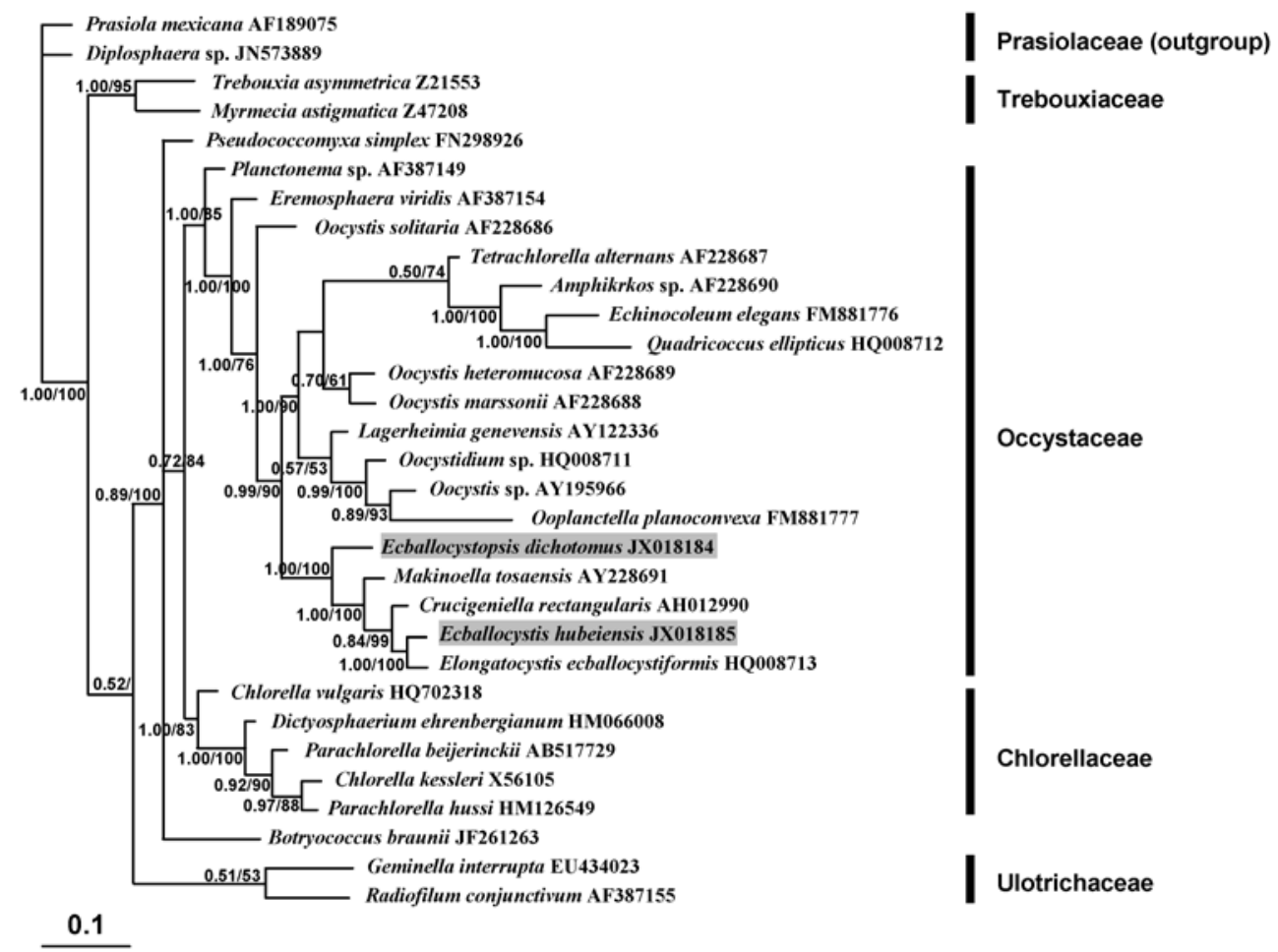

Fig. 25. Phylogenetic tree of $18 \mathrm{~S}$ rDNA sequences of members of Oocystaceae and relatives. Bayesian inference (BI) posterior probabilities and bootstrap support from maximum likelihood (ML) are presented on the nodes. Values above 0.50 for BI and 50 for ML are shown. The sequences obtained in our study are shaded gray.

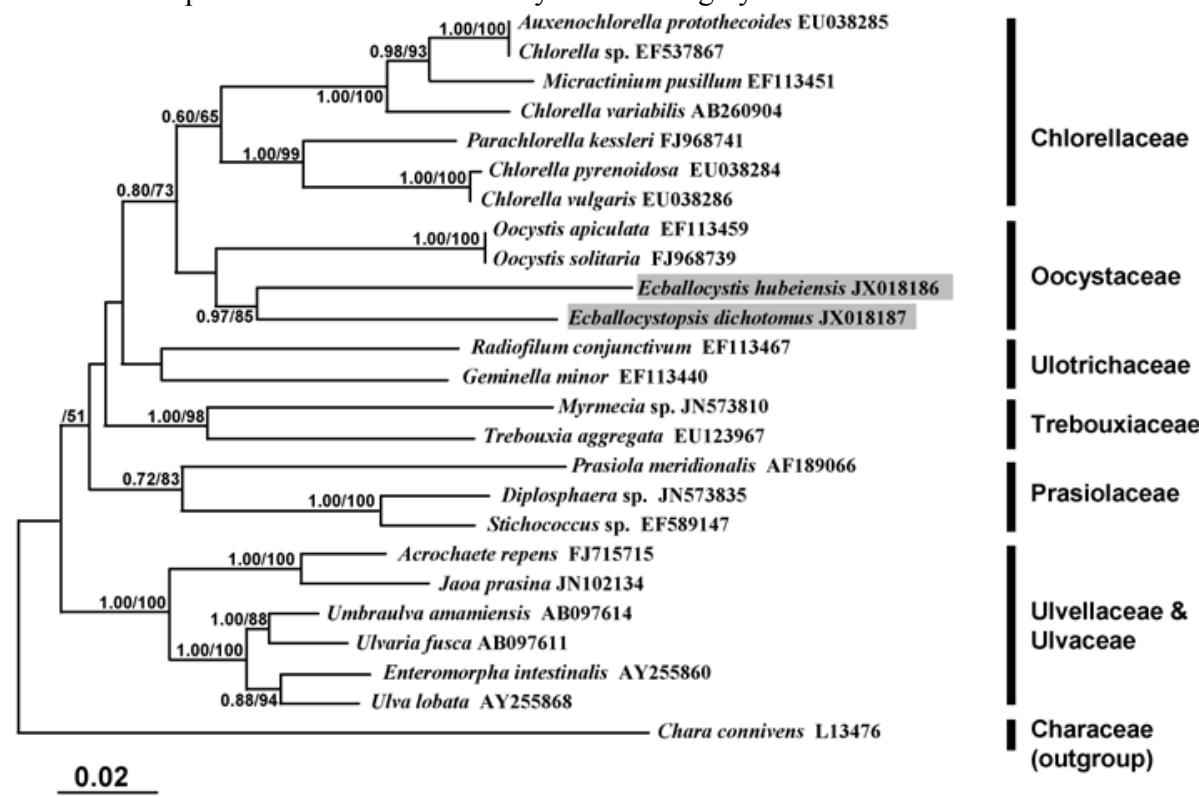

Fig. 26. Phylogenetic tree of $r b c \mathrm{~L}$ sequences of members of Oocystaceae and relatives. Bayesian inference (BI) posterior probabilities and bootstrap support from maximum likelihood (ML) are presented on the nodes. Values above 0.50 for BI and 50 for ML are shown. The sequences obtained in our study are shaded gray.

ML and BI had similar topologies. Only the Bayesian trees are presented. Most phylogenies reconstructed from $18 \mathrm{~S}$ rDNA dataset had strongly defined backbone topologies and well-supported internal clades (Fig. 25). In the 18S rDNA phylogenetic trees, species of the Oocystaceae formed a well-supported group (1.00/85 for BI/ $\mathrm{ML})$ with an interesting topology. Planctonema sp. (AF387149) and Eremosphaera viridis DE BARY (AF387154) were at the base, indicating relatively long phylogenetic distances between the two and other members of Oocystaceae. Oocystis solitaria 
WitTrock (AF228686) was positioned outside of a clade formed by the remaining members of Oocystis, and the paraphyly of the genus Oocystis was demonstrated. Ecballocystis hubeiensis and Ecballocystopsis dichotomus were unambiguously included in the Oocystaceae. E. hubeiensis showed the closest relationship to Elongatocystis ecballocystiformis (IYENGAR) KRIENITZ et Bock (HQ008713) with high support (1.00/100 for $\mathrm{BA} / \mathrm{ML})$. The interspecific pairwise divergence between $E$. hubeiensis from the present study and El. ecballocystiformis was $0.6 \%$, and only 11 sites were different. These two taxa represented a sister lineage to Crucigeniella rectangularis (NäGELI) KomÁreK (AH012990). Makinoella tosaensis OKADA (AF228691) clustered with these taxa, and the cluster represented a sister lineage to $E c$. dichotomus.

In the $r b c \mathrm{~L}$ gene phylogenetic tree, groups of green algae were well divided (Fig. 26). Members of Ulvellaceae and Ulvaceae were at the base of Chlorophyta. Ecballocystis hubeiensis and Ecballocystopsis dichotomus were closely related. The interspecific pairwise divergence between them was $1.46 \%$, and 152 sites were different. The two clustered into a subclade with high support $(0.97 / 85$ for $\mathrm{BA} / \mathrm{ML})$, and this subclade was sister to a lineage including two Oocystis member. But this position could not be clarified to due to the lack of statistical support. The Oocystaceae represented a sister lineage to the Chlorellaceae.

\section{Discussion}

Ecballocystis and Ecballocystopsis grow profusely in summer. Apart from China, the algae were reported to occur in hot areas in India, South Africa, and Réunion Island. Consequently, Ecballocystis and Ecballocystopsis are probably thermophilic algae.

Both the morphological and phylogenetic analysis in the present study indicated that Ecballocystis and Ecballocystopsis should be placed in the Oocystaceae, in agreement with IYengaR's (1932) conclusions. The two algae exhibit cell structures and multilayered cell walls resembling those of Oocystaceae, and their chloroplasts are especially characteristic of the group. Their chloroplasts were discoid shaped, parietal, and had a pyrenoid with a homogenous matrix surrounded by a thick starch sheath.
Thylakoids extend the length of the chloroplast and occur in stacks of three to five, but never traverse the pyrenoid matrix. The pyrenoid surrounded by a starch sheath and the arrangement of thylakoids were very similar to those of Oocystis (e.g. FotT \& ČAdo 1966; Maya et al. 2009; Pendland and ALDRICH 1973). Moreover, the two species were reported to reproduce in a manner very similar to other members of the Oocystaceae (Hu \& BI 1998; Liu \& Hu 2005). In our study, the algae produced 2,4 , or 8 autospores or daughter cells which were situated in their mother cell wall residues. The mother cell wall gradually changed into a colorless mucilage, which corresponded with previous observation on Oocystis nephrocytioides FOTT et ČADO (FotT \& ČADO 1966). However, the two algae are epiphytic, living in subaerial habitats, and their cells are arranged in large dendroid or filamentous colonies. In contrast, most members of Oocystaceae are planktonic, with cells that are either solitary or arranged in small colonies. These conflicting characteristics probably hindered former researchers from placing Ecballocystis and Ecballocystopsis in the family Oocystaceae.

One important feature of Oocystaceae is the multilayered cell wall. At least two discrete layers were reported in previous TEM study: the inner layer was composed of highly oriented microfibrils, and the microfibril of the outer layer was amorphous (RoBinson \& White 1972; SACHS et al. 1976; QuADER 1986).

Recently, phylogenetic analysis had been performed on Oocystis ecballocystiformis, a colonial member of Oocystaceae (KRIENITZ \& Bоск 2011). Cells of O. ecballocystiformis were arranged in loose colonies in a thick mucilaginous envelope. The authors excluded this taxon from the genus Oocystis because the phylogenetic distance between it and other Oocystis species was relatively large. A new genus Elongatocystis was suggested with the type species Elongatocystis ecballocystiformis (=Oocystis ecballocystiformis). When this alga was firstly described by IYENGAR (1932), he pointed out that it was possibly loose colonies of Ecballocystis fritschii based on morphological observation. In the present study, El. ecballocystiformis (HQ008713) was very close to E. hubeiensis (JX018185) as revealed in $18 \mathrm{~S}$ rDNA phylogenetic analysis. But E. fritschii and the type species of genus, E. indica was not sequenced up till now, we could not make the conclusion that El. ecballocystiformis was loose colonies of E. fritschii. 
Our placement of the two colonial subaerial algae, Ecballocystis and Ecballocystopsis, within the Oocystaceae emphasizes the morphologic complexity of the Oocystaceae. The Oocystaceae, as summarized in KoMÁReK and FotT (1983), are morphologically characterized by cell walls composed of several layers and the more or less spherical, ellipsoidal, or fusiform cells propagate by autosporulation. As presented by PAžOUTOVÁ et al. (2010), the family of Oocystaceae has a large phenotypic plasticity. Cells can be either solitary or colonial, with or without mucilage, and with different numbers of spines. Here, we added two subaerial algae that characteristically form macroscopic colonies to Oocystaceae. KRIENITZ \& BocK also thought the filamentous genus Planktonema was a candidate for inclusion in Oocystaceae (Krienitz \& Bock 2011). The thallus structure of Planktonema is very similar to that of Ecballocystopsis. Considering the large phenotypic plasticity within Oocystaceae, the phylogeny in this group could be of great interest.

Unfortunately, while much work has been done on the ecology and biochemical properties of Oocystaceae (e.g. ZAFAR 1967; ORCUTT \& Richardson 1970; Lee \& Picard 1983; Chang \& Sibley 1993; Lopez-Llorca \& Hernandez 1996; KovitvadHi et al. 1997), few taxa have been subjected to phylogenic analysis, and few DNA sequences are available (e.g. HepperLe et al. 2000; Pažoutová et al. 2010; Krienitz \& Bock 2011). MelKonian (1983) suggested including not only the "classical" oocystacean genera (Oocystis, Chodatella, Franceia and Lagerheimia) but also the chlorellacean genera (Chlorella, Tetraedron, Ankistrodesmus, Monoraphidium and Selenastrum) in the Oocystaceae. He concluded that this family was likely an artificial assemblage. Recently, the conventional concept of some chlorellacean genera were evaluated and phylogenetic works revealed relatively long distances between them and the "classical" oocystacean genera. The genus Chlorella, newly found to include taxa with a mucilaginous envelope and colonial lifeform was a member of Chlorellaceae (Luo et al. 2010; Bock et al. 2011). Tetraedron was placed on the monophyletic lineage of Hydrodictyaceae (Buchнегм et al. 2005). Ankistrodesmus, Monoraphidium and Selenastrum were ascribed to Selenastraceae (KRIENITZ et al. 2001; KRIENITZ et al. 2011). Meanwhile, according to HepperLe's phylogenetic analysis (2000), the number of taxa in the family Oocystaceae should be lower than
Melkonian (1983) suggested, and the family was an independent lineage. In the phylogenetic tree reconstructed in our study, the Oocystaceae members formed a well-supported clade with several subclades. We are inclined to approve of Hepperle's conclusion. The family Oocystaceae, with the high level of phenotypic plasticity, included taxa whose cell arrangement can be solitary, colonial, dendroid, or filamentous, form an early diverging clade within the Chlorellales (LELIAERT et al. 2012).

\section{Acknowledgements}

This research was financially supported by the Chinese National Nature Foudation No. 30970501.

\section{References}

Bischoff, H. W. \& Bold, H. C. (1963): Phycological studies. IV. Some soil algae from EnchantedRock and related algal species. - University of Texas Publications 6318: 1-95.

Bock, C.; Krienitz L. \& Pröschold, T. (2011): Taxonomic reassessment of the genus Chlorella (Trebouxiophyceae) using molecular signatures (barcodes), including description of seven new species. - Fottea 11: 293-312.

Bourrelly, P. (1966): Les algues d'eau douce. Initiation à la systématique. Tome I: Les algues vertes. - 512 pp., Ed. N. Boubée, Paris.

Bourrelly, P. (1972): Les algues d'eau douce. Initiation à la systématique. Tome I: Les algues vertes. - 572 pp., Ed. N. Boubée, Paris.

Bourrelly, P. (1988): Complements. Les algues d'eau douce. Initiation à la systématique. Tome I: Les algues Vertes. - 182pp., Paris.

Bourrelly, P. \& Coute, A. (1986): Algues d'eau douce de l'Ile Maurice (Diatomees exclues). - Rev. Hydrobiol. Trop. 19: 131-158.

Buchheim, M.; Buchheim, J.; Carlson, T.; Braband, A.; Hepperle, D.; Krienitz, L.; Wolf, M. \& Hegewald, E. (2005): Phylogeny of the Hydrodictyaceae (Chlorophyceae): inferences from rDNA data. - J. Phycol. 41: 1039-1054.

Chang, C. \& Sibley, T. (1993): Accumulation and transfer of copper by Oocystis pusilla. - B. Environ. Contam. Tox 50: 689-695.

Doyle, J. J. \& Dickson, E. E. (1987): Preservation of plant samples for DNA restriction endonuclease analysis. - Taxon 36: 715-722.

Fritsch, F. E. (1918): Contributions to our knownledge of the freshwater algae of Africa. II. - Ann. S. Afr. Mus. 9: 483-611.

FritsCh, F. E. (1956): The structure and reproduction of the algae. I. - 791 pp., Cambrige University 
Press, Cambridge.

FotT, B. \& ČADO, I. (1966): Oocystis nephrocytioides sp. nov. - Phycologia 6: 47-50.

Gouy, M.; Guindon, S. \& Gascuel, O. (2010): SeaView version 4: a multiplatform graphical user interface for sequence alignment and phylogenetic tree building. - Mol. Biol. Evol. 27: 221-224.

Hepperle, D.; Hegewald, E. \& Krienitz, L. (2000): Phylogenetic position of the Oocystaceae (Chlorophyta). - J. Phycol. 36: 590-595.

Hu,Z.Y.\& BI, L. J.(1998):Ecballocystopsis dichotomus sp. nov. (Chlorococcales, Chlorophyceae) from China. - Biologia-Bratislava 53: 403-408.

Huelsenbeck, J. P. (2001): Bayesian inference of phylogeny and its impact on evolutionary biology. - Science 294: 2310-2314.

IYENGAR, M.O.P. (1932): Two little-known genera of green algae (Tetrasporidium and Ecballocystis). - Ann. Bot. 46: 191-192.

IYENGAR, M.O.P. (1933): Ecballocystopsis indica n. gen. et sp., a new member of Chlorodendrales. - Ann. Bot. 47: 21-25.

KomÁreK, J. \& FotT, B. (1983): Chlorophyceae (Grünalgen), Ordnung: Chlorococcales. - In: Huber-Pestalozzi, G. (ed.): Die Binnnengewässer 16/7. - 1044 pp., E. Schweizerbart'sche Verlagsbuchhandlung, Stuttgart.

Kovitvadhi, U.; Chaopaknam, B. \& Nagachinta, A. (1997): Ecology of freshwater pearl mussel, Hyriopsis (Limnoscapha) myersiana (Lea, 1856) in Maeklong river, Kanchanaburi province. Kasetsart J. (Nat. Sci.) 32: 1-12.

KrienitZ, L. \& Bock C. (2011): Elongatocystis ecballocystiformis gen. et comb. nov., and some reflections on systematics of Oocystaceae (Trebouxiophyceae, Chlorophyta). - Fottea 11: 271-278.

Krienitz, L.; Bock, C.; NozAKi, H. \& Wolf, M. (2011): SSU rRNA gene phylogeny of morphospecies affiliated to the bioassay alga "Selenastrum Capricornutum" recovered the polyphyletic origin of crescent-shaped Chlorophyta. - J. Phycol. 47, 880-893.

Krienitz, L.; Ustinova, I.; Friedl, T. \& Huss, V. A. R. (2001): Traditional generic concepts versus $18 \mathrm{~S}$ rRNA gene phylogeny in the green algal family Selenastraceae (Chlorophyceae, Chlorophyta). - J. Phycol. 37: 852-865.

LeE, B. \& PicARD, G. (1983): Occurrence of glutamate dehydrogenase isoenzymes during growth of Oocystis Alga. - Biotechnol. Bioeng. 25: 18011816.

Leliaert, F.; Smith, D. R.; Moreau, H.; Herron, M. D.; Verbruggen, H.; Delwiche, C. F. \& De Clerck, O. (2012). Phylogeny and molecular evolution of the green algae. - Crit. Rev. Plant. Sci. 31:
$1-46$.

LiU, G. X. \& Hu, Z. Y. (2005): Ecballocystis hubeiensis sp. nova (Chlorococcales, Chlorophyceae) from China. - Algological Studies 116: 39-47.

Lopez-Llorca, L. \& Hernandez, P. (1996): Infection of the green alga Oocystis lacustris chod with the chytrid fungus Diplochytridium deltanum (masters) karling. An SEM study. - Micron 27: 355-358.

Luo, W.; Pflugmacher, S.; Pröschold, T.; Walz, N. \& KRIENITZ, L. (2006): Genotype versus phenotype variability in Chlorella and Micractinium (Chlorophyta, Trebouxiophyceae). - Protist 157: 315-333.

Luo, W.; Pröschold, T.; Bock, C. \& Krienitz, L. (2010): Generic concept in Chlorella-related coccoid green algae (Chlorophyta, Trebouxiophyceae). - Plant Biology 12: 545-553.

Mathews, D. H.; Sabina, J.; Zuker, M. \& Turner, D. H. (1999): Expanded sequence dependence of thermodynamic parameters improves prediction of RNA secondary structure. - J. Mol. Biol. 288: 911-940.

StoyneVA, M. P.; IngOlIć, E.; Gärtner, G. \& VyVERman, W. (2009): The pyrenoid ultrastructure in Oocystis lacustris Chodat (Chlorophyta, Trebouxiophyceae). - Fottea 9: 149-154.

Meduin, L.; Elwood, H. J.; Stickel, S. \& Soqin, M. L. (1988): The characterization of enzymatically amplified eukaryotic 16S-like rRNA-coding regions. - Gene 71: 491-499.

Melkonian, M. (1983): Phylum Chlorophyta. - In Margulis, L.; Corliss, J. O.; Melkonian, M. \& Chapman, D.J. (eds): Handbook of Protoctista. - pp. 597-660, Jones \& Barlett, Boston.

Orcutt, D. \& Richardson, B. (1970): Sterols of Oocystis polymorpma, a green alga. - Steroids 16: 429-446.

Pažoutová, M.; Škaloud, P. \& Nemjová, K. (2010): Phylogenetic position of Ooplanctella planoconvexa, gen. et comb. nova and Echinocoleum elegans (Oocystaceae, Trebouxiophyceae, Chlorophyta). - Fottea 10: 75-82.

Pendland, J. C. \& Aldrich, H. (1973): Ultrastructural organization of chloroplast thylakoids of the green alga "Oocystis marssonii". - J. Cell. Biol. 57: 306-314.

Posada, D. \& Crandall, K. A. (1998): Modeltest: testing the model of DNA substitution. Bioinformatics 14: 817-818.

PRASAD,A.K.S.K.(1985):Ecballocystopsisdesikacharyi sp. nov. (Chlorodendrales, Chlorophyta) from India: structure and reproduction. - Phycologia 24: 241-243.

Quader, H. (1986): Cellulose microfibril orientation in Oocystis solitaria: Proof that microtubules control the alignment of the terminal complexes. 
- J. Cell. Sci. 83: 223-234.

Reynolds, E. S. (1963): The use of lead citrate at high $\mathrm{pH}$ as an electron-opaque stain in electron microscopy. - J. Cell. Biol. 17: 208-212.

Robinson, D. G. \& White, R. (1972): The fine structure of Oocystis apiculata W. West with particular reference to the wall. - Brit. Phycol. J. 7: 109118.

Sachs , H.; Grimm, J. \& Robinson, D.G. (1976): Structure, synthesis and orientation of microfibrils. I. Architecture and development of the wall of Oocystis solitaria. - Cytobiology 14: 49-60.

Swindell, S. \& Plasterer, T. (1997): SEQMAN. Contig assembly. - Methods Mol. Biol. NLMID 70: 75-89.

SwOFFord, D. L. (1998): PAUP*: Phylogenetic analysis using parsimony (*and other methods), version 4.0. Sinauer, Sunderland, Massachusetts.

Tamura, K.; Dudley, J.; Nei, M.; Kumar, S. (2007): MEGA4: molecular evolutionary genetics analysis (MEGA) software version 4.0. - Mol. Biol. Evol. 24: 1596-1599.

Thompson, J. D.; Gibson, T. J.; Plewniak, F. \& Higgins, D. G. (1997): The CLUSTAL $X$ windows interface: flexible strategies for multiple sequence alignment aided by quality analysis tools. - Nucleic acids res. 25: 4876-4882.

ZAFAR, A. (1967): On the ecology of algae in certain fish ponds of Hyderabad, India. - Hydrobiologia 30: 96-112.

Zechman, F. W. (2003): phylogeny of the Dasycladales (Chlorophyta, Ulvophyceae) based on analyses of rubisco large subunit $(r b c \mathrm{~L})$ gene sequences. - J. Phycol. 39: 819-827.

(C) Czech Phycological Society (2013)

Received June 25, 2012

Accepted October 29, 2012 